\title{
CORRECTION
}

\section{Correction to: Voice recognition package for ERTU's cloud}

\author{
Salwa M. Serag Eldin ${ }^{1} \cdot$ Mohammed A. Alsharqawy $^{2}$
}

Published online: 18 August 2020

(c) Springer Science+Business Media, LLC, part of Springer Nature 2020

\section{Correction to: \\ International Journal of Speech Technology (2017) 20:51-67 \\ https://doi.org/10.1007/s10772-016-9387-8}

Mohammed A. Alsharqawy is co-author of above mentioned article, but was not listed in the author group of the original article.

Publisher's Note Springer Nature remains neutral with regard to jurisdictional claims in published maps and institutional affiliations.

The original article can be found online at https://doi.org/10.1007/ s10772-016-9387-8.

Salwa M. Serag Eldin

sserag@gmail.com

Mohammed A. Alsharqawy

mnm_1946@hotmail.com

1 Electronics and Electrical Communications Engineering Department, College of Engineering, Tanta University,

Tanta, Egypt

2 Egytian Radio and Television Union, Cairo 1186, Egypt 